\title{
DEBT CAP REGULATIONS IN MORTGAGE LENDING
}

Donát Kim

\begin{abstract}
In this paper I study debt cap regulations in retail mortgage lending in Hungary introduced by the National Bank of Hungary. I believe the introduction of debt cap regulations was justified, but the toolkit applied should be reviewed. After studying international examples and reviewing the literature, I have concluded that LTV (loan-to-value) regulation correspond to European practice and researchers' findings. While the introduction of LTI (loan-to-income) ratio should be considered to replace PTI (payment-to-income) ratio, as it is more stable in time and there is no incentive to switch between the increase of risk factors and the increase of the maximum amount regulated by law by PTI regulation.
\end{abstract}

JEL codes: G21, G28, G51, G53, K23

Keywords: debt cap regulations, default, real-estate related lending, PTI, LTI, LTV, loan term (maturity), rate fixing

\section{INTRODUCTION}

Compared to international regulatory authorities, the National Bank of Hungary is proactive in its regulatory politics. The number one actor of financial stability has marked views on the threats to and future role of our financial system. In this paper I review the debt cap regulations in mortgage lending as one of the many instruments used by the National Bank. According to the 2016 Macroprudential Report, the grounds for the introduction of debt cap regulations was to 'prevent repeated retail over-lending' like at the 2008 financial crisis. In addition, it is 'able to prevent over-indebtedness of individual households so it can mitigate the impact of the cyclical aspects of the financial mediation system' (MNB, 2016). The objective of this paper is to analyse if the debt cap regulations are in line with the objective, with particular attention to the mitigation of default rates in mortgage lending.

1 Donát Kim, PhD student, Budapest Corvinus Doctoral School of Economics, Business and Informatics.E-mail: donat.kim@uni-corvinus.hu. 
Three indicators and their variants are prevalent in mortgage lending. In this country, the loan-to-value ratio (Hungarian: HFM) and the payment-to-income ratio (Hungarian: JTM) relate to mortgage lending. I argue in my paper that HFM regulations are efficient and based on consensus, meanwhile, the introduction of income related to the loan amount rather than to the repayment amounts would be more adequate to test borrowers' creditworthiness. Applying the LTI ratio is less incentive in terms of channelling borrowers towards a riskier loan product. Due to its simpler calculation, economic policy regulation is easier to be planned for regulators, while borrowers can also calculate the maximum loan amount easier. Since the available maximum loan amount is given, borrowers will face conversion in terms of expenses to risk. Reviewing European regulations, you can see that LTV regulations are nearly similar in the countries of the European Economic Area, though in many countries discounts are provided for first home buyers. On the contrary, the countries apply alternately PTI and LTI regulations, furthermore PTI regulations often are hand-in-hand with maximisation of maturity. For this reason, I analysed how different debt cap regulations can predict default risk. According to international literature, LTV rules at disbursement are significant, however, the assessment of PTI at disbursement is not consistent in the 21 studies I have reviewed. PTI at disbursement was significant to estimate default in three cases (Linn-Lyons, 2020; Chamboko-Bravo, 2020 és Kelly-O'Toole, 2018), but it was not significant at 10 percent significance level in three other studies (Demyanyk-Loutskina, 2016; Berkovec-Canner-Hannan-Gabriel, 2018 és Yilmazer-Babiarz-Kiss, 2012), while it was omitted from the final econometric model in several cases. However, the current PTI ratio was significant in all cases where it was included as an independent variant, so in terms of loan monitoring it is an effective ratio to predict default.

Next, I analysed two trends observed in mortgage lending in Hungary, the spread of variable rate loans and the lengthening of maturity, which were analysed in the November 2017 Financial Stability Report, and the 2020 Macroprudential Report, respectively. I believe both trends are coherent with the efforts of certain borrowers to maximise loan amounts available under the PTI rule. Summing up the above, I have concluded that the National Bank of Hungary should consider the introduction of a maximum LTI ratio instead of the PTI regulations. The LTI debt cap is currently applied in several European countries, so a wide range of knowledge is available for its introduction. Its advantage as opposed to PTI is that LTI at disbursement is static, it is not exposed to the cycle component of the risk environment. In addition, my study could be a useful starting point for researchers of the topic and bank risk managers because of the wide range of the data processed and the summary of international literature in this paper. 
In the first part of my paper, following a description of debt cap regulations in Hungary, I review the European stage. Next, I briefly summarise fixed rate and variable rate interests and the walk-away-right as two major issues in international literature. In the third part I present the relevant studies using Scopus for systematic search and briefly sum up major findings. In the fourth part I point out the risks of income related instalments with the help of model calculations and elementary statistics. Finally, I sum up the major findings in the conclusion.

\section{DEBT CAP INDICATORS}

In the field of retail lending, mortgage loans for housing are the most important and most significant in the product range of commercial banks since assistance to buying homes is a central issue for most governments. However, regulations and support for home buying are highly varied in the different countries.

The common feature of retail mortgage loans is that their ticket sizes are high compared to the borrower's work income, they are standardised, secured by mortgage rights and long term. They are disbursed to natural persons at interest rates lower than unsecured loans. The types, interest rates, repayment schedules, cover, purpose, or legal limitations of the contracts may change significantly from country to country. The objective of macroprudential regulations is to mitigate systematic risk. Compiled by the different regulatory authorities, they are based on the local environment and quite varied depending on the additional risks, extreme lending expansion or toxic asset categories found with credit institutions. Regulatory authorities have a choice of two sets of instruments: they can either drive the sector with capital adequacy requirements, or they can introduce restrictive measures or counter non-desirable schemes. The so termed debt cap regulations belong to the latter category.

It is obvious that banking regulations and credit risk management highly rely on the debt cap regulations establishing a connection between borrowers' financial position and the main parameters of the loan product disbursed.

The first is the loan-to-value ratio, or HFM indicator, comparing the initial own funds of households to the loan requested. It is calculated by dividing the amount of the loan to be disbursed by the estimated value of the property mortgaged. From now on, it will appear as LTV ratio in this paper. The second one is the payment-to-income (PTI) or mortgage-payment-to-income (MTI), debt-serviceto-income (DSTI), debt-service-coverage ratio (DSCR) or debt-to-income (DTI), abbreviated as JTM in Hungarian. Here you have the monthly debt service in the numerator and the verified monthly income in the denominator. In certain cases, DTI and PTI ratios are managed separately, because the latter is only calculated 
for the debt service of one loan, while repayments of all loans are considered for DTI. I will use the term PTI from now. Finally, I analyse the loan-to-income (LTI) ratio. There is no term or acronym for it in Hungarian banking terminology, however, it is the ratio of the loan amount disbursed to the verified annual net income. Sometimes DTI is used as an alternate of LTI ratio. Since both international literature and the banking profession use the English terms and because there is no Hungarian equivalent for LTI, I am going to use the English acronyms from now on.

The LTV ratio indicates the borrower's own funds, i.e., the minimum loss incurred by the borrower in case of non-payment, so it is linked to willingness-topay, since higher own funds reduce the borrower's moral risk. Compared, PTI and LTI create a link between the borrower's income position and the loan. PTI is typically monitored monthly, while LTI is checked at the beginning of the loan as it will show how many years of the client's total (current) net income would be sufficient to recover the total loan amount. These indicators are intricately linked to the client's ability to pay.

\section{REGULATIONS IN HUNGARY AND EUROPE}

I have collected the current debt cap regulations from the website of the ESRB (European Systemic Risk Board), where summaries of the current macroprudential legal provisions of 31 countries are available. The data were downloaded from the website on 06.03.2021, however, the data base was last updated on 22.02.2021, so the data content can be deemed topical. Debt cap regulations were divided into four large groups, such as loan-to-value (LTV), loan-to-income (LTI or DTI), debt service (DSTI or PTI) and length of maximum maturity. In this paper I do not discuss the temporary measures implemented in connection with COVID-19 and I also omitted the analysis of macroprudential regulations related to consumer loans or non-mortgage housing loans.

In Hungary, the PTI (JTM) and LTV (HFM) type regulations are in effect. However, contrary to the accepted legal practice of European countries, debt cap regulations are subject to the loan type, its denomination, interest period and the borrower's income. The following table presents maximum PTI ratios subject to monthly net income and interest period. 
Table 1

PTI rules in Hungary

\begin{tabular}{cccc}
\hline \multirow{2}{*}{ Monthly net income } & \multicolumn{3}{c}{ Interest period } \\
& Up to 5 years & $\mathbf{5}$ years - 10 years & 10 years - end of maturity \\
\hline Up to 500th HUF & $25 \%$ & $35 \%$ & $50 \%$ \\
500th HUF or above & $30 \%$ & $40 \%$ & $60 \%$ \\
\hline
\end{tabular}

Source: MNB Directive No 32/2014. (IX. 10.)

For Euro-denominated loans, the initial PTI ratio can have $15 \%$ to $30 \%$ as maximum value, for other currencies it is $5 \%$ to $15 \%$. Their progressive pricing - like that of Forint loans - depends on the borrower's income and the interest period. With LTV there are different limit values for financial leases and loans presented in the following table.

Table 2

LTV regulations in Hungary

\begin{tabular}{ccc}
\hline Currency & Loan & Financial lease \\
\hline Forint & $80 \%$ & $85 \%$ \\
Euro & $50 \%$ & $55 \%$ \\
Other & $35 \%$ & $40 \%$ \\
\hline
\end{tabular}

Source: MNB Directive No 32/2014. (IX. 10.)

The Hungarian macroprudential regulations specifically stipulate that if child support loan was applied for not more than 90 days prior to buying the property, $75 \%$ of it can be used as own funds, or $100 \%$ of it if the loan application is older than 90 days.

Macroprudential regulations were also identified in MNB Directive No 32/2014 (IX.10.) For PTI, the maximum ratio was set at $60 \%$ like in the regulations currently in effect, but no differentiation was made by interest periods, and the income margin was set at HUF 400,000 rather than HUF 500,000. As of o1 October 2018, differentiation by interest periods was introduced and the net income was raised to HUF 500,000 on o1 July 2019. LTV rules have remained essentially unchanged.

After the Hungarian regulations, I have summed up the LTV, LTI, PTI and maturity figures of different countries based on the ESRB database in the next table. The table only includes mandatory legislative provisions, recommendations are indicated in the footnotes. 
Table 3

Debt cap regulations in EEA countries

\begin{tabular}{|c|c|c|c|c|}
\hline Country & $\begin{array}{c}\text { LTV maximum } \\
\text { ratio }\end{array}$ & $\begin{array}{c}\text { LTI maximum } \\
\text { ratio }\end{array}$ & $\begin{array}{c}\text { PTI maximum } \\
\text { ratio }\end{array}$ & $\begin{array}{c}\text { Maximum } \\
\text { maturity }\end{array}$ \\
\hline \multicolumn{5}{|l|}{ Austria $^{2}$} \\
\hline \multicolumn{5}{|l|}{ Belgium $^{3}$} \\
\hline \multicolumn{5}{|l|}{ Bulgaria } \\
\hline Cyprus $^{4}$ & $80 \%$ & & $80 \%$ & \\
\hline Czech Republic ${ }^{5}$ & $90 \%$ & & $50 \%$ & \\
\hline Denmark $^{6}$ & $95 \%$ & & & \\
\hline United Kingdom & & 4.5 & & \\
\hline Estonia & $85 \%$ & & $50 \%$ & 30 years \\
\hline Finland & $90 \%$ & & & \\
\hline France & & 7 & $35 \%$ & 25 years \\
\hline \multicolumn{5}{|l|}{ Greece } \\
\hline The Netherlands & $100 \%$ & & & 30 years \\
\hline \multicolumn{5}{|l|}{ Croatia } \\
\hline Ireland ${ }^{6}$ & $80(90 \%)$ & 3.5 & & \\
\hline Iceland ${ }^{7}$ & $85(90 \%)$ & & & \\
\hline Poland ${ }^{8}$ & $80-90 \%$ & & $40-50 \%$ & 35 years \\
\hline Latvia9 & $90 \%$ & 6 & $40 \%$ & 30 years \\
\hline Lichtenstein $^{10}$ & $80 \%$ & & & \\
\hline
\end{tabular}

2 In Austria, the relevant Guidelines recommend $80 \%$ for LTV, $30-40 \%$ for PTI and 35 years as maximum maturity.

3 In the Belgian Recommendation LTV is set at 90\%, LTI at 9 times the loan amount and PTI at $50 \%$.

4 In Cyprus and Slovakia, the income in the denominator is adjusted by the average cost of living for PTI/DSTI ratios.

5 As of or April 2020, the Czech Republic revoked the 9-times LTI recommendation, but the 30year maximum maturity is still in effect.

6 In the Guidelines, the LTI ratio is recommended at below 7 , if it is higher than 4, special management is recommended.

7 In Ireland and Iceland, the values for first home buyers are in brackets.

8 In Poland, a client may draw a loan with 50\% PTI if their salary is above average in their region, or with $40 \%$ PTI if it is below average. LTV is $80 \%$ but can go up to $90 \%$ if there is sufficient liquid cover.

9 In Latvia 95\% LTV is possible with state guarantee.

10 In Lichtenstein loan disbursement is possible with less than $80 \% \mathrm{LTV}$, but the loan file must be marked „exception to policy”. 


\begin{tabular}{|c|c|c|c|c|}
\hline Country & $\begin{array}{l}\text { LTV maximum } \\
\text { ratio }\end{array}$ & $\begin{array}{l}\text { LTI maximum } \\
\text { ratio }\end{array}$ & $\begin{array}{l}\text { PTI maximum } \\
\text { ratio }\end{array}$ & $\begin{array}{c}\text { Maximum } \\
\text { maturity }\end{array}$ \\
\hline Lithuania & $85 \%$ & & $40 \%$ & 30 years \\
\hline Luxembourg ${ }^{6}$ & $90(100 \%)$ & & & \\
\hline Hungary & $80 \%-85 \%$ & & $25-60 \%$ & \\
\hline Malta $^{11}$ & $90 \%-85 \%$ & & $40 \%$ & $25-40$ years \\
\hline \multicolumn{5}{|l|}{ Germany } \\
\hline Norway & $85 \%$ & 5 & & \\
\hline \multicolumn{5}{|l|}{ Italy } \\
\hline Portugal $^{12}$ & $90 \%$ & & $50 \%-60 \%$ & 40 years \\
\hline Romania $^{13}$ & $85 \%$ & & $40 \%$ & \\
\hline \multicolumn{5}{|l|}{ Spain } \\
\hline Sweden & $85 \%$ & & & \\
\hline Slovakia ${ }^{4}$ & $90 \%$ & $8-9$ & $70 \%$ & 30 years \\
\hline Slovenia $^{14}$ & & & $50 \%-67 \%$ & \\
\hline
\end{tabular}

Source: https://www.esrb.europa.eu/national_policy/shared/pdf/esrb.measures_overview_macroprudential_measures.xlsx

The Hungarian regulations are among the most complex, which drives clients to opt for categories deemed less risky by the authorities.

Incentives for a favourable composition of loan products can be found in other countries too, but they are different from Hungarian practice, because additional rules relate to the portfolio of the institutions in those cases. In Slovakia, the Czech Republic, Estonia, France, Latvia, Luxembourg, Malta, and Norway the ratios are stipulated, i.e., what part of a portfolio can be made up of the loans of the segment deemed the riskiest. In Lithuania, the stress PTI of the portfolios

11 In Malta clients are divided into category I or II based on complex legal criteria. Category I aims to support home buying, 40-year maturity or maturity until retirement age are allowed. LTV may be $90 \%$ in category I and $85 \%$ in category II reduced to $75 \%$ as of 01.07 .2021 . For PTI, clients in category II must comply, in addition, with the impact of a 150-bp interest shock.

12 In Portugal, the LTV ratio for properties purchased for purposes other than owner-occupation is $80 \%$. In 20 percent of new disbursements, credit institutions have the possibility to lend at a PTI above 50 percent but below 60 percent.

13 In Romania LTV is $85 \%$ for loans denominated in LEI, $80 \%$ for hard-currency-denominated loans provided the borrower has also income in the currency, $75 \%$ for EUR loans and $60 \%$ for other currencies. For PTI, the limit is $20 \%$ for currency loans unless there is natural hedge income.

14 In Slovenia PTI is 50\% until the double of the minimum wage and $67 \%$ above that. Higher PTI than the legal maximum can be allowed up to $10 \%$ of a new disbursement, but it cannot exceed $67 \% .80 \% \mathrm{LTV}$ recommendation is also in effect. 
is analysed, assuming $5 \%$ reference interest rate in the stress test. There is some room for manoeuvre in the countries listed, still, the regulations prevent extreme systematic risk. It is also noticeable that there is a higher number of regulations in the post-Socialist countries. Finding the reasons for such difference would be an interesting area for research. They might be a lower level of financial awareness of the population in those countries, or a negative risk competition by institutions on the mortgage market, a higher demand for rules by the population or the paternalistic approach of the state.

\section{OTHER MODELLING ASPECTS OF MORTGAGE LENDING}

Before starting to analyse the impact of different ratios as seen in international literature, one must understand the different practices of mortgage lending in the different countries. Different lending provisions and contract terms may cause major deviations on default. Let me call attention here to two outstanding contract terms, one is the walk-away-right and the other is the type of interests.

In a simplified way, the walk-away-right - or limited liability for mortgage loans - means the borrower can decide to cede their property to the credit institution, and the credit institution forecloses the collateral. In that way, the borrower has no more obligations to the credit institution independent of whether the value of the property is lower than the outstanding loan debt. This lending scheme is typical in certain states of the US. In Europe, in contrast, the borrower must repay the loan amount. So, if the borrower defaults, and the property taken over and auctioned by the bank fails to recover the outstanding loan amount, the borrower may not only lose their property in an extreme case, but they will still owe the bank a major amount.

I considered it important to check in international literature which market was used for a basis, since the assumptions for empirical studies or the premise for modelling might be different, which would lead to different conclusions. American authors focus their research on strategic default, which says the client could but would not pay due to high deficiency (negative equity). Negative equity is the outcome of the loan value exceeding property value. LTV ratios are more emphatic with these models, as the analysis is focused on willingness to pay.

An interesting empirical finding is that contrary to the basic idea, borrowers are typically willing to pay their mortgages even if equity is negative. According to a paper on the topic most frequently cited (Bhutta-Dokko-Shan, 2010), $80 \%$ of default occurred when payment difficulties and negative equity were both present. Half of the borrowers opted for strategic default when property prices were reduced by almost $50 \%$. Several explanations were offered why borrowers con- 
tinued to pay with negative equity. Bhutta, Dokko and Shan 2010 say the reason why making payments is still worth even if the loan value exceeds collateral can be explained by the complex tax rules, since mortgage payments reduce one's taxable base for personal income tax. According to other explanations, the stigma, the high transactional expenses of moving and eviction, or poor debtor rating by credit institutions due to reputational damage can be the reason for seemingly illogical mortgage payments. This is also supported by the findings of Guiso, Sapienza and Zingales (2013), who analysed the probability of strategic default with the help of questionnaires. They included features unrelated to financial issues, such as gender, ethnic minority or even political attitude and views on banks as explanatory variables, all of which proved significant.

Finally, Deng, Quigley, and Van Order (2000) compiled a real option model based on pricing. According to the model, instalments are a kind of option fee assuming property prices will rise again. Continuing repayment is worth to a borrower, otherwise - if they stop payments and the bank repossesses their house - the process is irreversible, they will have no more chance to possess, or sell and make early repayment if the real estate market recovers.

There is no walk-away-right in Hungary, so we have to take this into account if studies allow strategic default options It should be noted that in the event of negative equity further collection is not binary and is subject to many other factors, for instance, the time of the eviction, or the type of mortgage right enforcement, i.e., whether the creditor can only seize the collateral via court proceedings or in another way, typically via a notary public (Enoch et al., 2013). Hungarian decision makers should consider that in some western countries you can take out insurance for such a case, i.e., if a borrower is still in debt after their property has been foreclosed and auctioned, the insurer will cover the difference. Such insurance contracts are termed gap insurance.

Another important issue in credit agreements is whether the loan interest is fixed or variable. Although it may seem a clear definition, the meaning of fixed and variable rate loans may differ by banks or by countries. In English language studies one can find fixed-rate mortgage (FRM), where the interest rate is fixed till maturity; and there is adjustable-rate mortgage (ARM), where interest rate is defined as the sum of a certain reference rate and loan premium or spread. Reference rates are reviewed from time to time as stipulated in the contract, and the interest payable is calculated according to the outstanding principal until the next review date. Pursuant to MNB regulations, credit institutions in Hungary may deem a mortgage loan product to be fixed rate if the interest period of the reference rate is 5 years or longer. The Central Bank paid special attention to the comparison of fixed and variable rate mortgage loans in their 2017 Financial Stability Report. The authors said, “...fixed-rate loans, however, provide longer-term safety for debtors. 
The price for this is the higher interest rate upon borrowing in the case of a rising yield curve. However, if the interest rate difference between variable-rate and fixed-rate products contains only the effect of the expected interest rate path, the cost of the two products is offset during the interest rate period as a whole" (Financial Stability Report, November 2017). Nevertheless, the interest of fixed-rate loans adjusted by the inter-bank rate of the relevant maturity or by interest swap was higher in Hungarian banks. According to the credit institutions, the reason for that was to offset the loss incurred on the early termination of the interest rate swaps used to hedge fixed-term loans in the event of early repayment.

Partly to reduce the risk of interest rate increase, the National Bank of Hungary set up the Certified Consumer-Friendly Housing Loan classification system. In addition, two more unconventional instruments, i.e., 5 and 10-year monetary policy IRS facilities and a mortgage bond purchase programme were introduced in January 2018 to mitigate risks. Additionally, to mitigating "long-term interest risk", the Central Bank support interest rate fixation since "the probability of interest rate increase is higher on a few years' timescale than of their further reduction" (MNB, 2017).

In this paper, fix (hereinafter: FRM) means loans with fixed rates until the end of term and variable (hereinafter: ARM) means loans with interest rates re-priced monthly or in every 3 months in line with the relevant reference rate. In US studies, where there is a walk-away-right, another central issue is how interest fixing affects default. Contrary to the Financial Stability Report, Campbell 2013 argued that the initial and expected future instalments of ARM loans are lower on the US market than those of FRM ones, since there is a historical rise of yield curves. The empirically higher rate of default of ARM loans is explained by saying that lower initial instalments can be alluring for people who expect high income increase, so they plan to purchase a property that is expensive compared to their current income level. So, in many cases, ARM borrowers commit themselves to stretched instalments pushing the limits of their current incomes. On the other hand, FRM borrowers are characterised by risk avoidance, maximising loan amounts is less typical for them. This supports a statement in the Stability Report, „variable-rate is often coupled with lower incomes, higher amount of loan and longer maturity, which indicates that financially stretched households are more urged to choose the variable rate because of the interest rate spread" (MNB, 2017).

Fuster and Willen (2017) made a step further, arguing that not only initial instalments are lower, but ARM loans are more advantageous in a crisis, since - due to monetary stimulus - central banks reduce interest rates, so instalments may also be reduced significantly. Empirical data show that the state of the economy positively correlates with interest rate levels. So, reference rates decline in a recession, so the instalments of ARM loans are reduced, while the central bank increases 
interest rates in economic recovery. This increases instalments, but debtors in a favourable economic environment can either take out a replacement loan or sell their property as the real estate market expands and prepay their loan with the increased instalment. On the opposite, instalments are fixed for FRM loans, so borrowers do not enjoy the benefits of reduced interest rates, but they are not affected by increasing rates either.

However, the lessons of the 2008 crisis showed that most borrowers indebted in FRM had no possibility to swap their loans for ones with more favourable rates although reference rates declined. Overall, the set of monetary instruments lose their effectiveness. Still, it is underlined that ARM can be even more unfavourable in certain situations, for instance, in stagflation. Campbell and Cocco (2015) came to a similar conclusion based on their simulation model, where the default probability and interest margins of ARM and FRM loans were analysed. The above three papers studied the US market. Both empirical research and modelling might have come up with different findings in the case of a small open country having its own currency. In such a country an economic crisis can bring about a currency crisis, as it happened in Hungary after 2008.

Overall, it can be stated that the exposure to nominal interest levels of variablerate loans is cash-flow risk as well, which is borne better by a financial enterprise than a natural person. If interest is fixed, bearing the risk of real interest is a kind of discounting risk affecting net present value. A change in the net present value of a loan appears in the asset position, so it will not affect a client's liquidity position even if interests increase in real terms, but financial institutions must manage net present value risk, as the effect of revaluation impact equity. Another problem is that in the case of APR the risk from interest change is not quantified, so loans with shorter interest periods look disproportionately favourable, as it is presented by Berlinger (2019) in his study.

\section{DEBT CAP INDICATORS IN INTERNATIONAL LITERATURE}

I carried out systematic search in Scopus of Elsevier, one of the largest academic publishing houses of the world, setting the filtering criteria in Table 4 using combinations of the following words to search in key words, titles, and abstracts. 
Table 4

Search words in Scopus

\begin{tabular}{ccc}
\hline & AND & \\
\hline Mortgage & Default & LTV \\
Housing loan & Delinquency & Loan to Value \\
& Foreclosure & PTI \\
& & Payment to Income \\
& DTI \\
& Debt to Income \\
& MTI \\
& LTI \\
& & Loan to Income \\
& DSCR \\
& DSTI
\end{tabular}

The search engine produced 102 studies for the combinations. Reading the abstracts, 21 relevant papers remained. Their major findings are presented in table format.

The first column in the Table includes authors' names and date of publication.

The second column presents the data, i.e., the data of which country were analysed, when and how many observations were made. They help place the study in context and identify any potential limitations. In the third column the process applied is presented. For econometric models, their explanatory power and the definition of dependent variables is also presented. In most models the probability of default was modelled, while default may vary by countries and periods. Default in most models was set after 90 days of non-payment of instalments. In the fourth column the ratios are presented with their impact on default, or - for economic models - according to their part played in the models.

Next, I analysed other explanatory variables of econometric models. This partly helps understand the gradient of ratios exercised on default, and partly is a starting point for modellers to select the relevant studies.

Finally, I summed up the major findings and the conclusions made by the authors from the given studies. The short abstracts are not sufficient to learn the whole content, they focus on the description of the part played by the ratios in the models. 


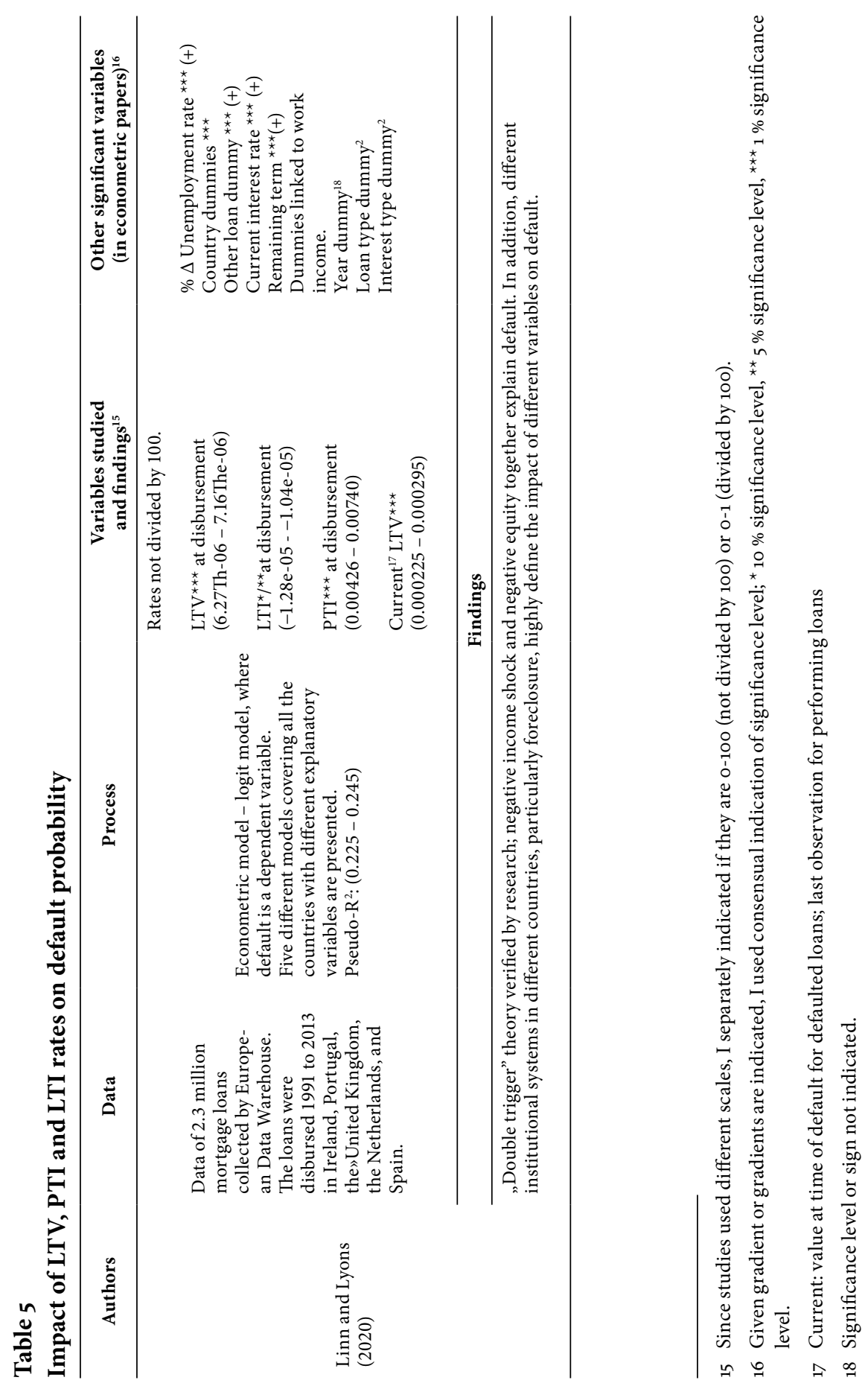




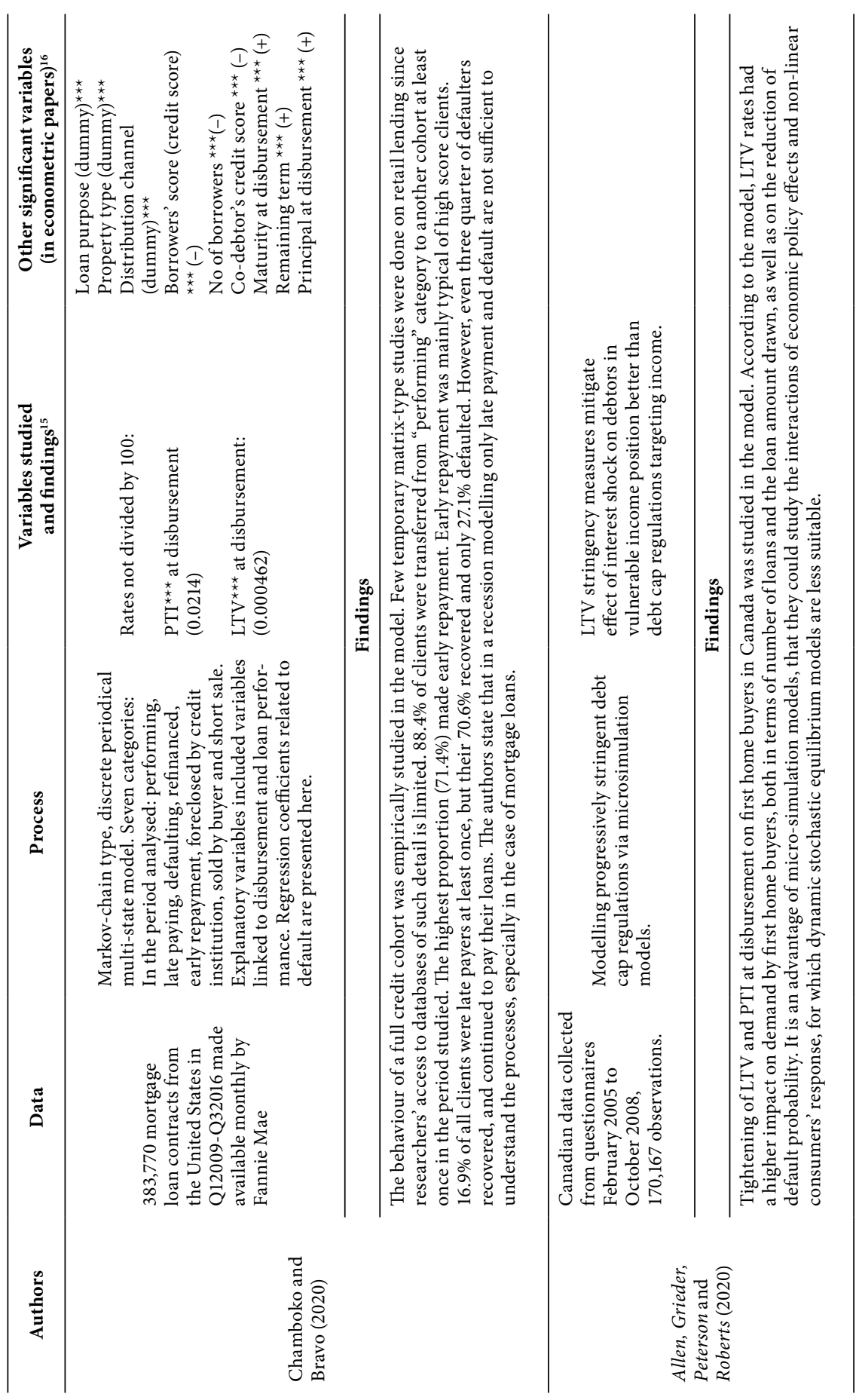




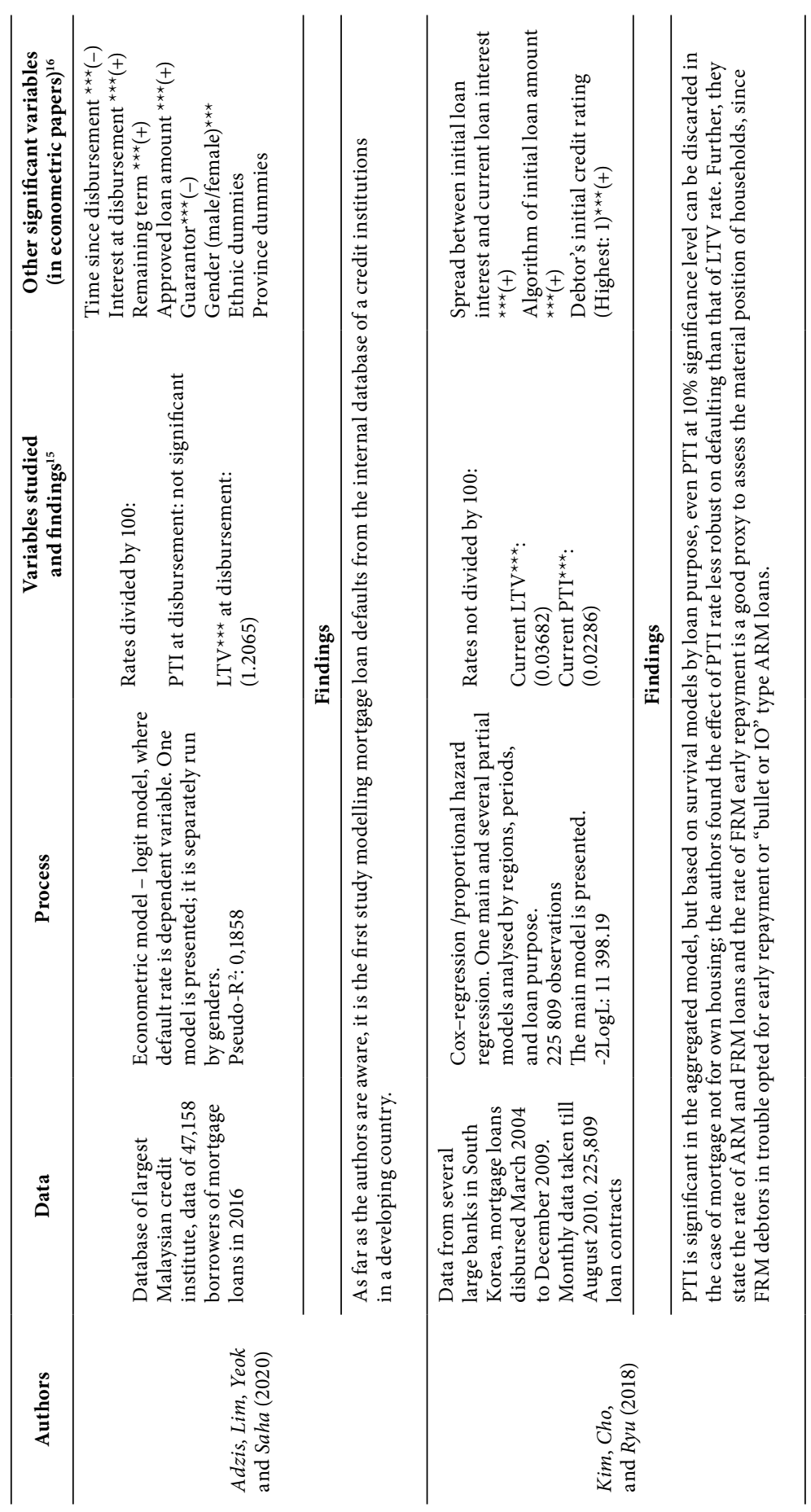




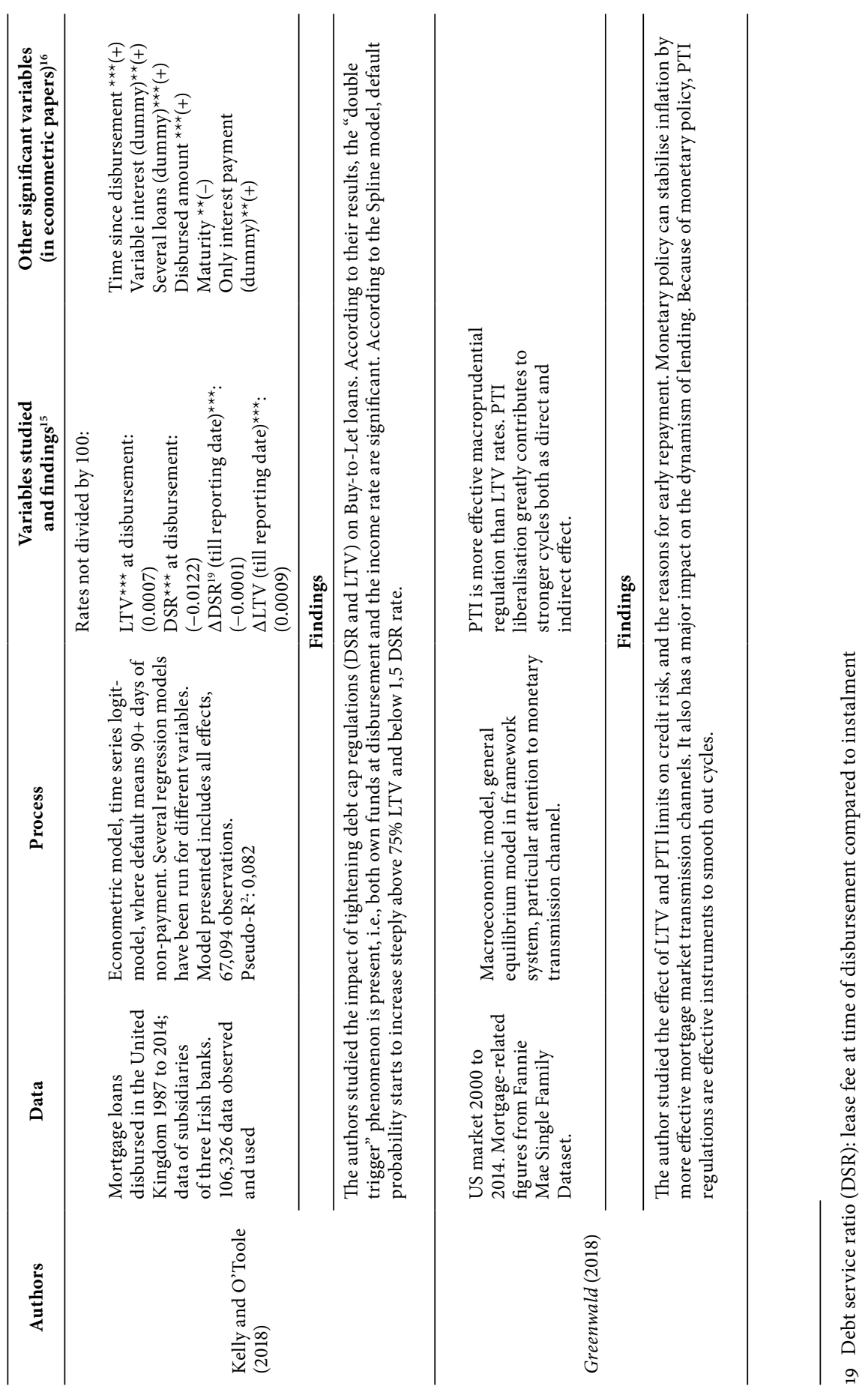




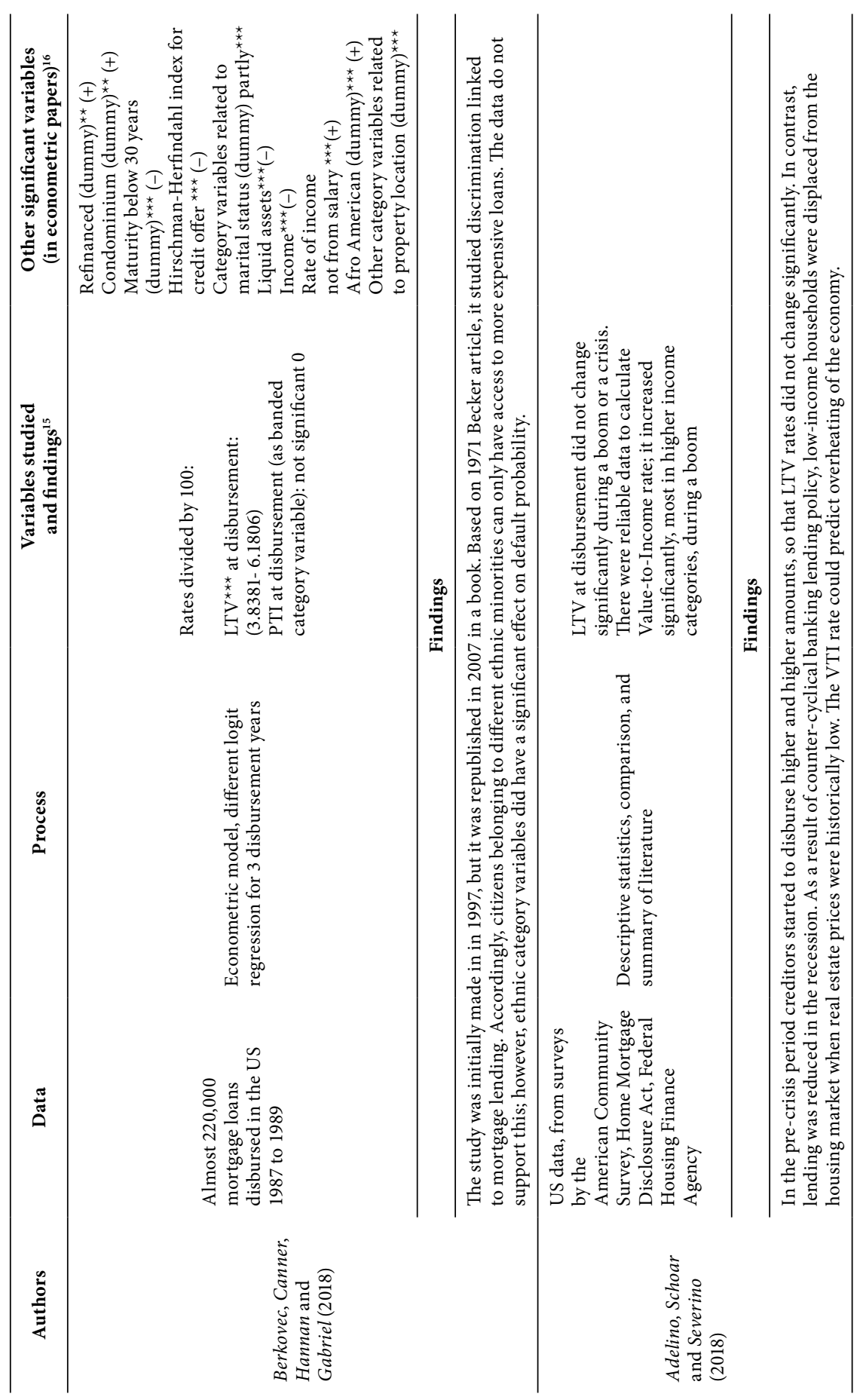




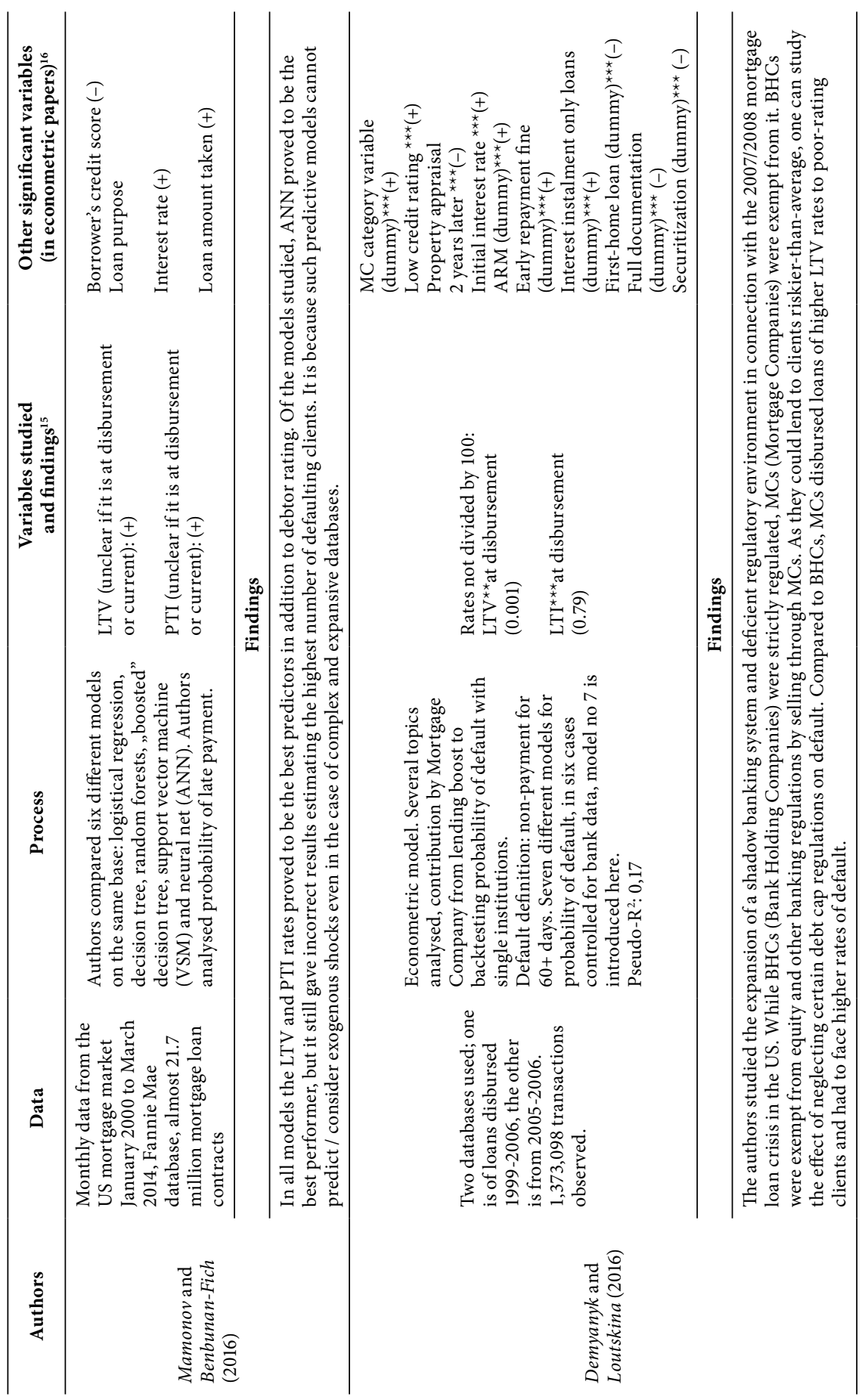




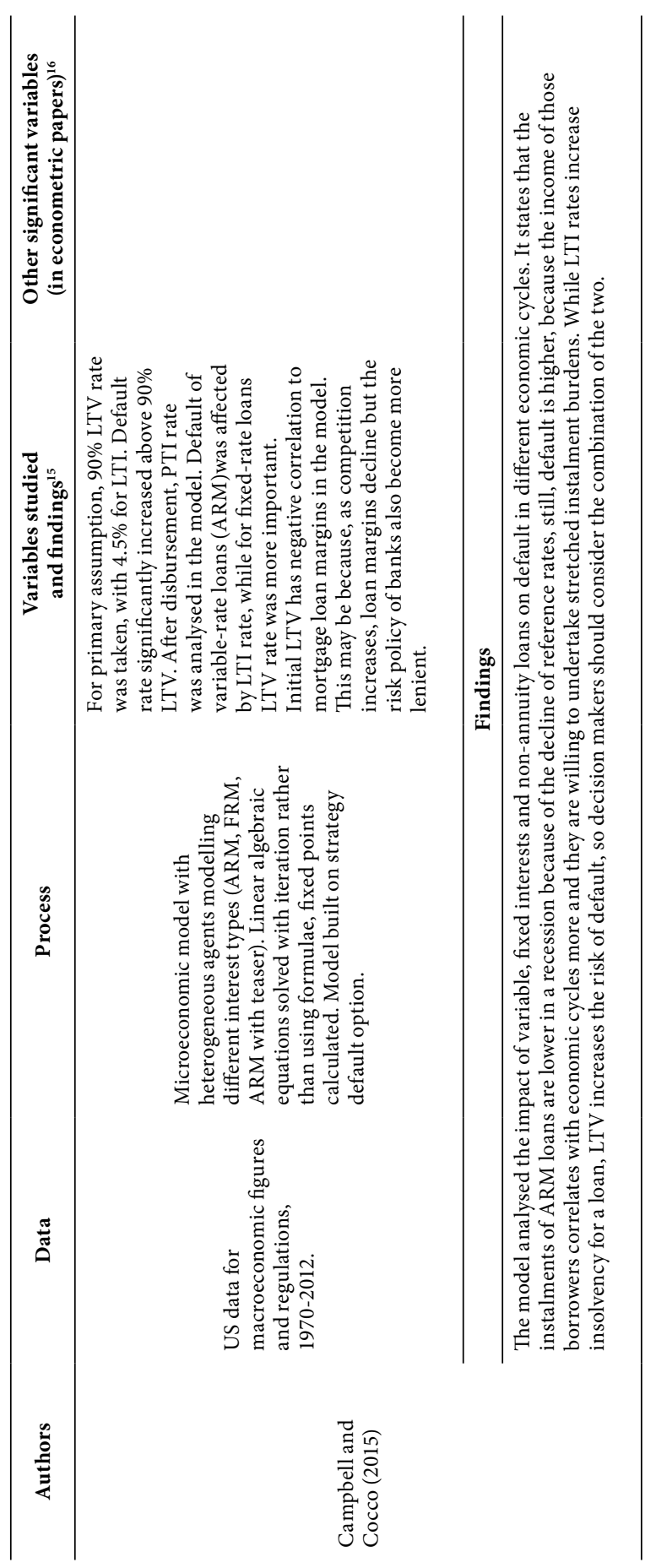




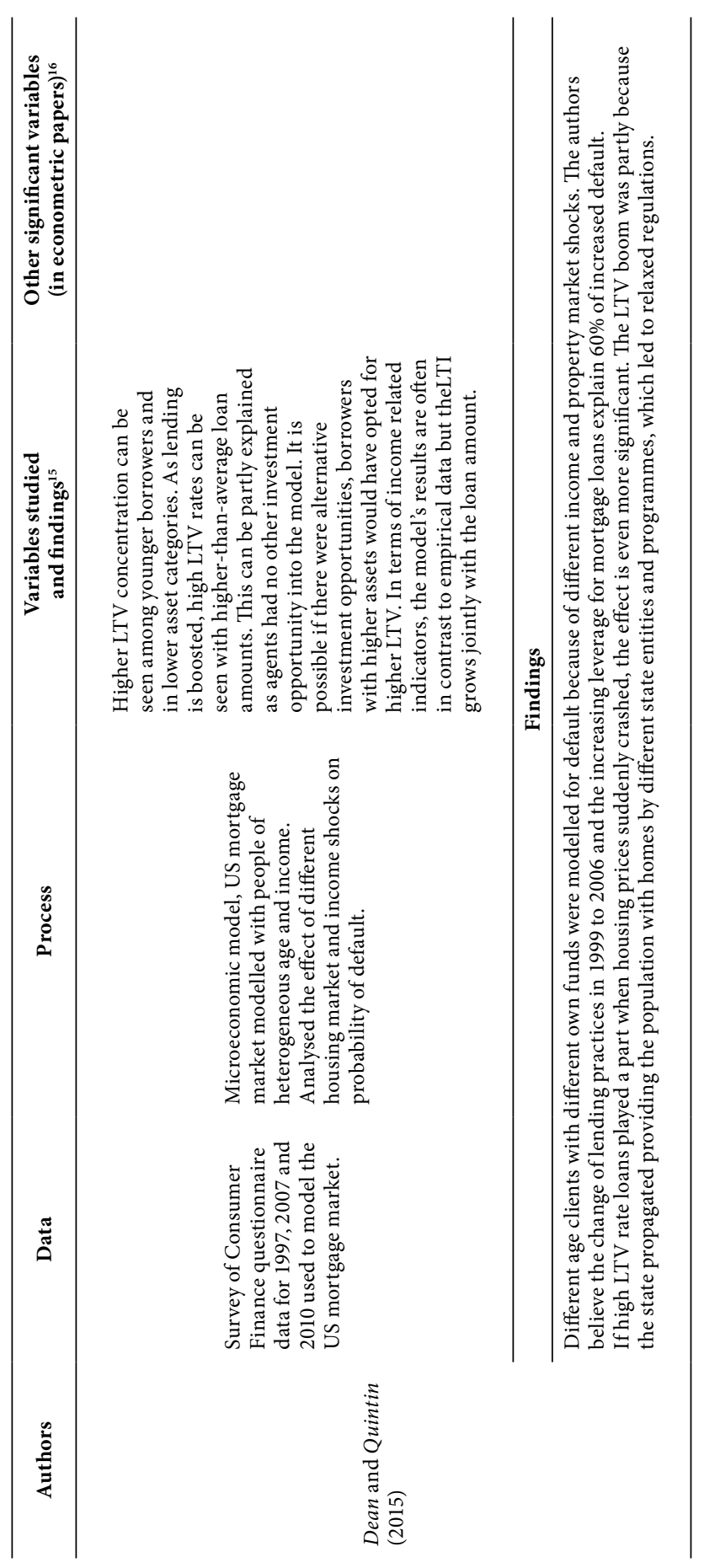




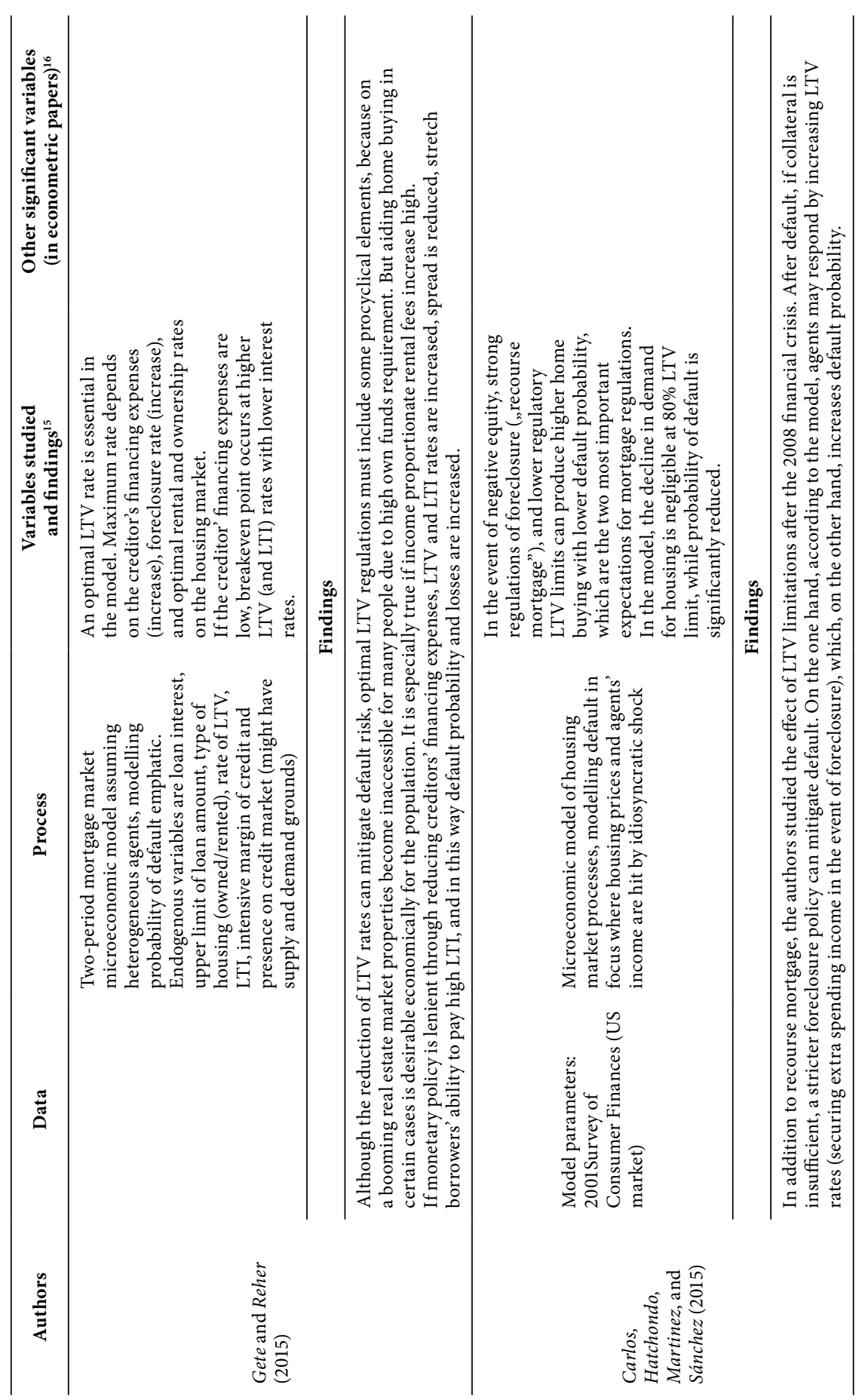




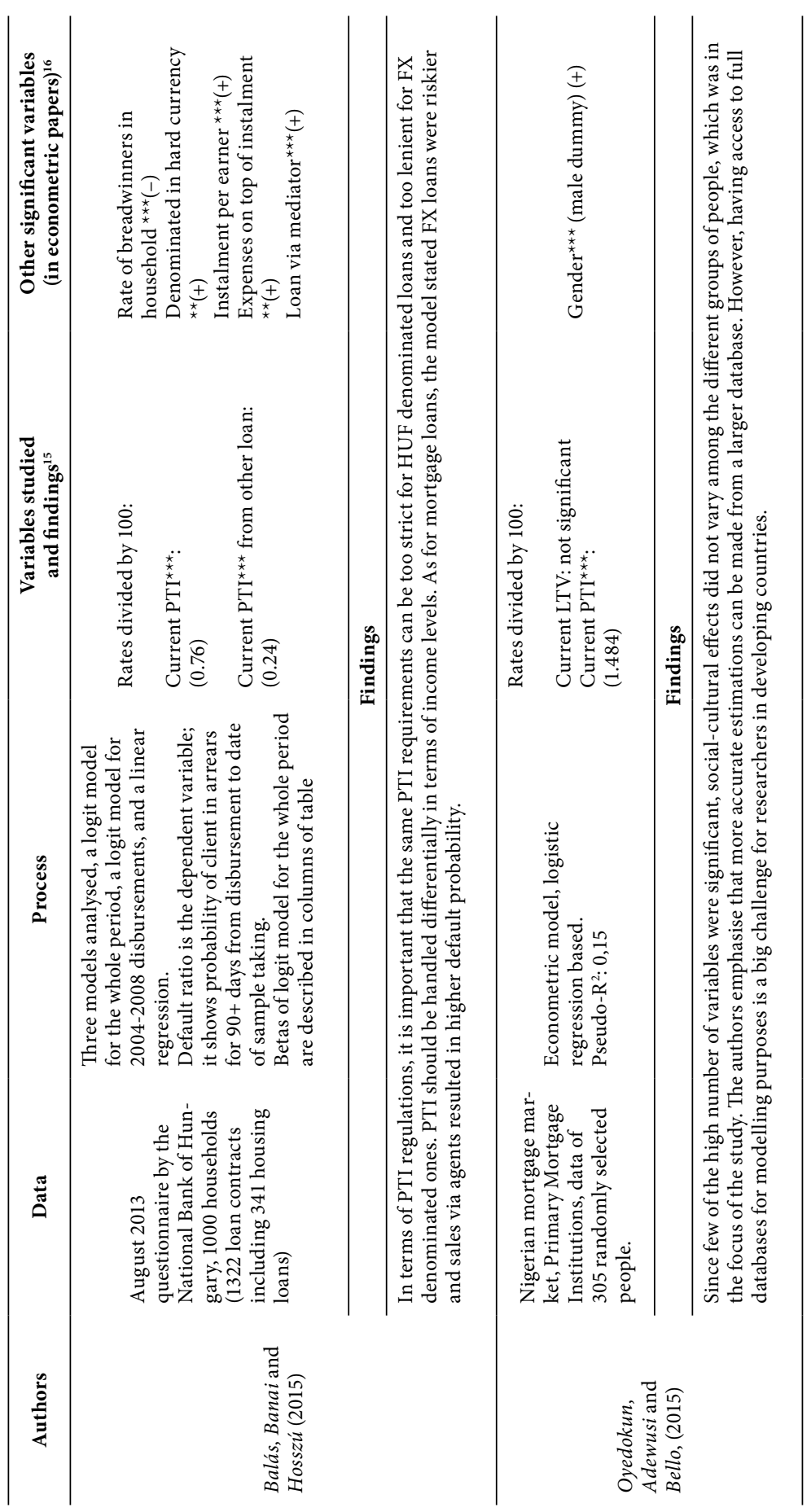




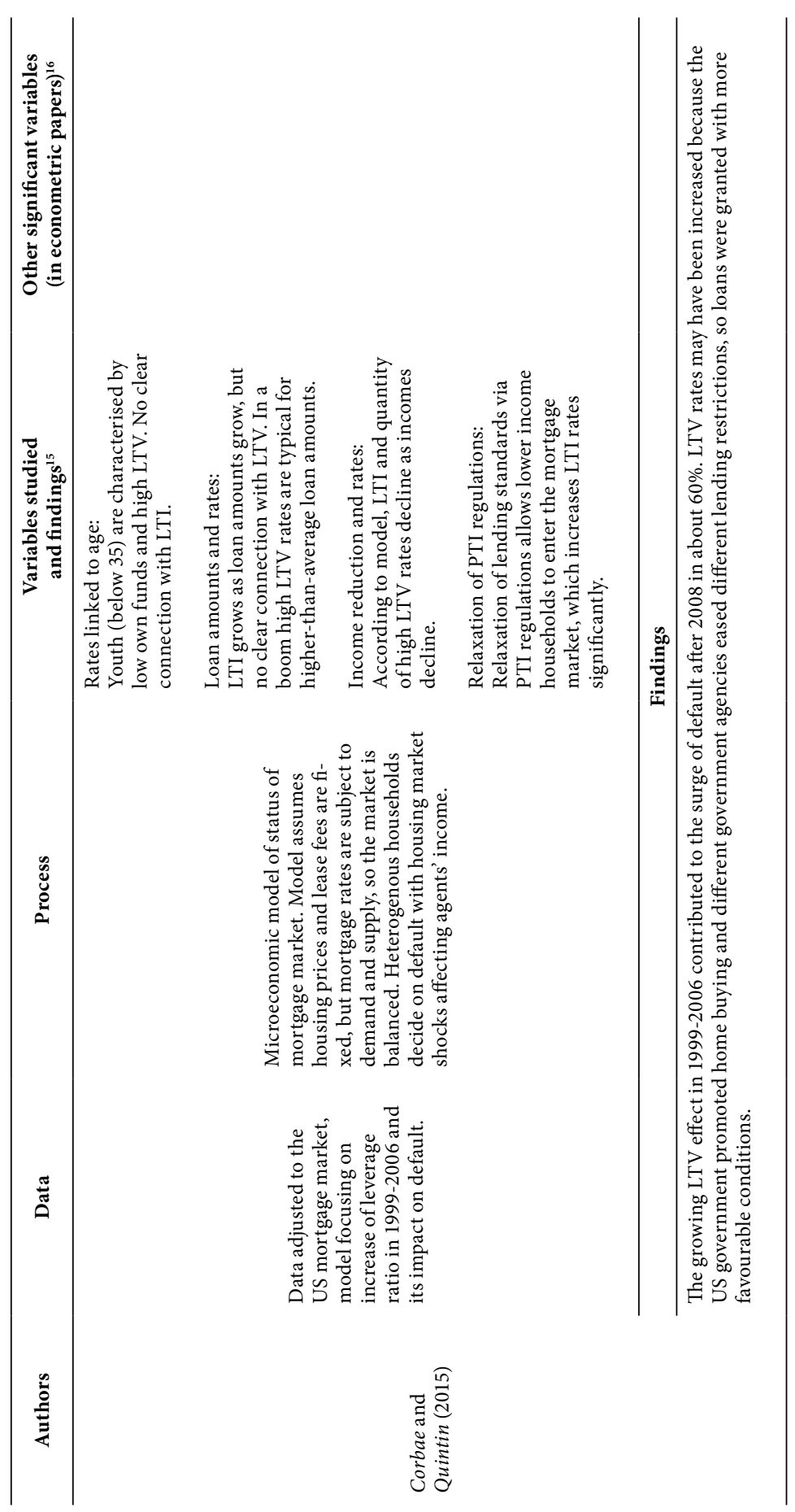




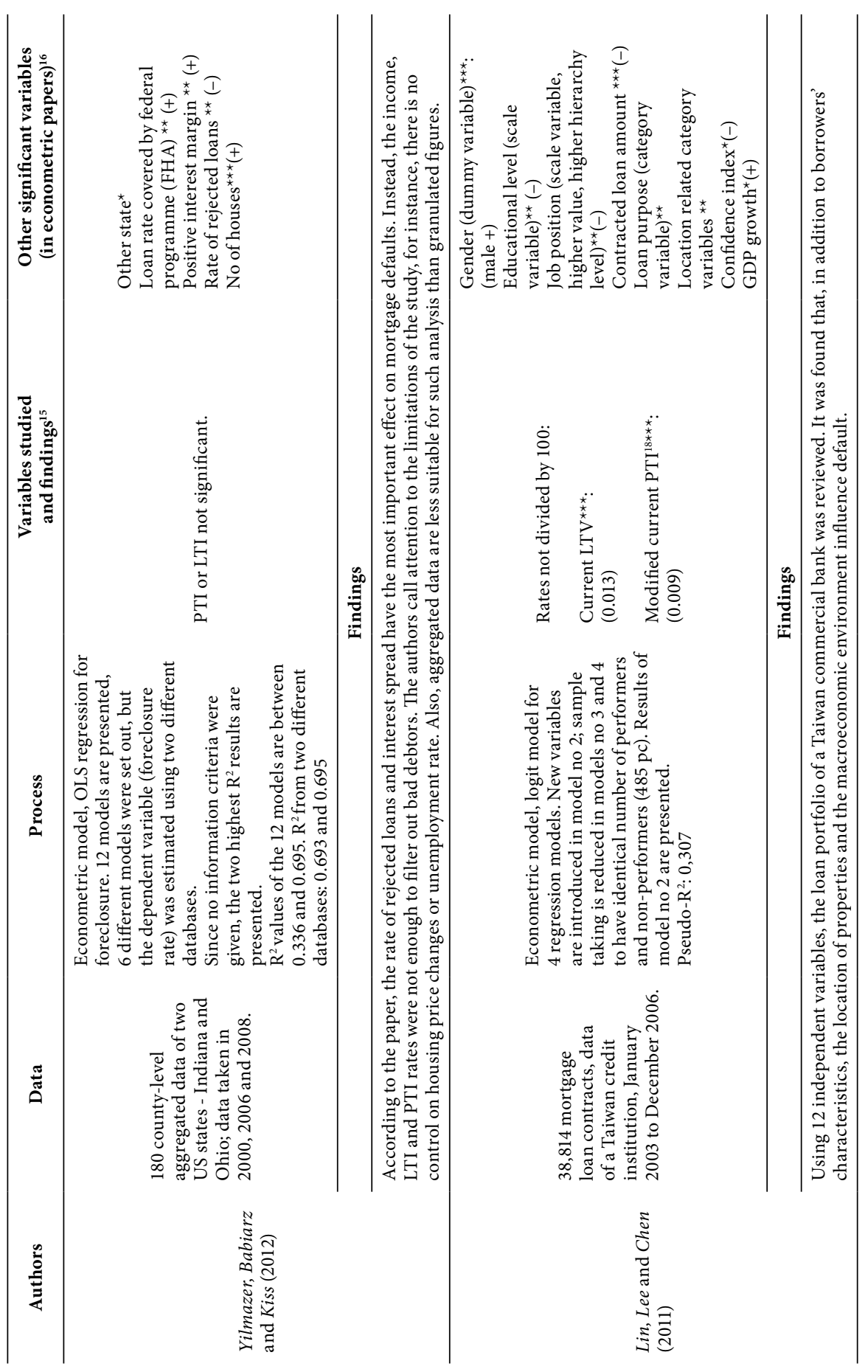




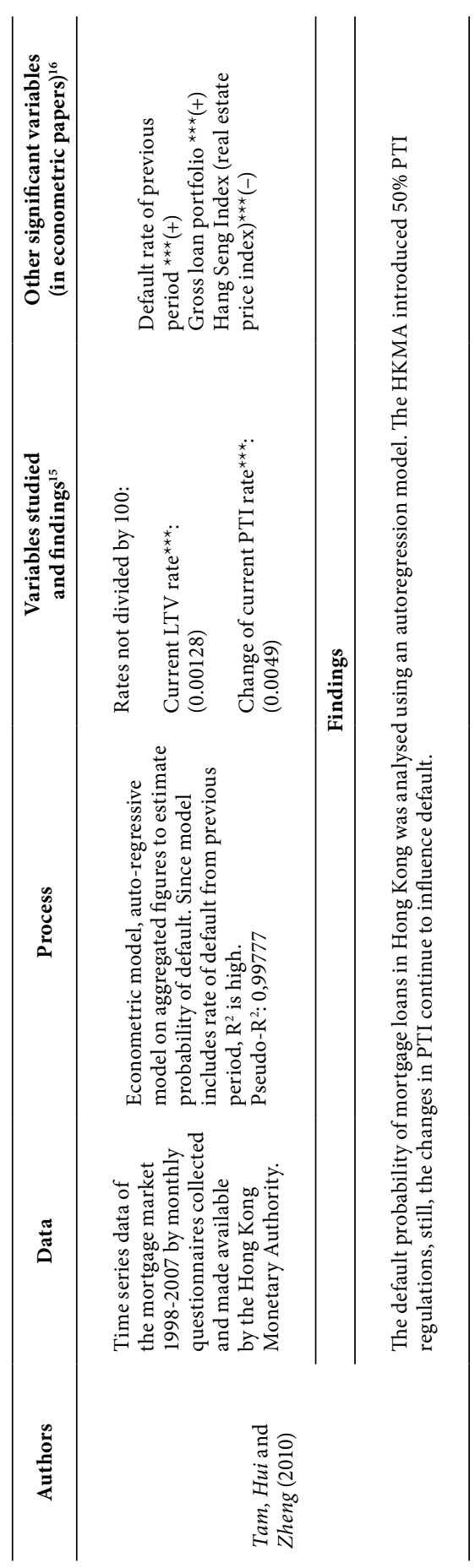


There is consensus in international literature that the "double trigger" phenomenon is present in retail mortgage lending, i.e., the presence of both own funds and solvency indicators (PTI and LTI) matter. Studying LTV is exciting on its own. Institutional environment including foreclosure options influence optimum size. Most studies, which tried to identify an effective regulatory limit found over $80 \%$ significant increase of default probability. Harrison, Noordewier, Yavas (2004) studied if defaulting debtors had high LTV. According to their econometric model, if default expenses are higher, good debtors are willing to choose higher LTV because of a kind of self-selection and sign value. However, if default expenses are moderate, risky clients will choose high LTV rates.

On the contrary, the picture is far from being uniform in terms of solvency rates (LTI and PTI). In the case of PTI, the rate of instalment to income is a better approach to assess solvency, but PTI rates at disbursement and current PTI rates need to be separated. The current PTI situation clearly defines the solvency of a household; it is significant in most models. However, the correlation between PTI at disbursement and solvency is not so clear. PTI at disbursement was significant for default estimation in three cases (Linn and Lyons, 2020; Chamboko and Bravo, 2020; and Kelly and O'Toole, 2018), but it was not significant at $10 \%$ in three other studies (Demyanyk and Loutskina, 2016; Berkovec, Canner, Hannan and Gabriel, 2018; and Yilmazer, Babiarz and Kiss, 2012), while it was omitted from the final econometric model in several cases. In economic models, such as Campbell and Cocco (2015) or Gete and Reher (2015), the LTI rate is typically analysed at disbursement for loan contracts, because one must use extra assumptions for the loan in case of PTI.

\section{IMPACT OF PTI REGULATIONS ON MAXIMUM LOAN AMOUNT}

For annuity loans the instalment $(P)$ can be calculated by the following formula, where $(R)$ is effective interest, $(P V$ - present value) is the loan amount disbursed and $(n)$ is maturity:

$P=\frac{(P V * R)}{1-\left[\frac{1}{1+R}\right]^{n}}$

So, the instalment depends on the interest rate, maturity, loan type and the loan amount drawn. Those were significant recurring variables in default modelling. The formula shows that the loan amount can be increased if contractual interest rate is lower, or if maturity is prolonged. 
According to the Central Statistical Office (KSH), the net average salary of fulltime employees excluding benefits was HUF 334,238 in Budapest in Q4 2020. As an example of calculation, I studied the difference among loan amounts granted in the event of a (rounded) HUF 350,00o net salary with different maturities and interest rates pursuant to the current $\mathrm{MNB}$ regulations

\section{Figure 1}

Maximum loan amount granted with net income of HUF 350,000 and $50 \%$ PTI compared to maturity and interest rate.

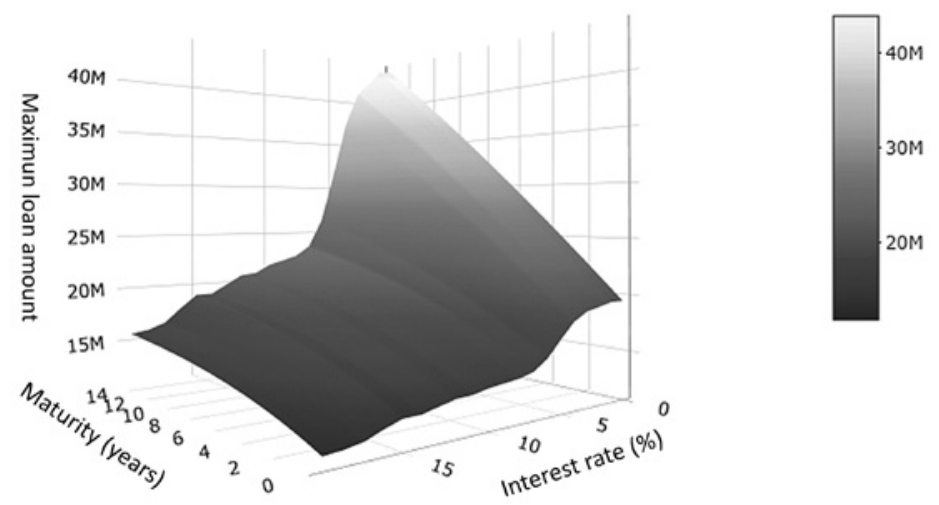

Note: see in table format in the Annex.

Provided there are no progressive PTI regulations, and the debt cap regulation is effective, a client can increase their loan amount granted if they take out the loan with longer maturity or at a lower interest rate. Under normal market conditions, variable interest rates result in lower loan interest. It is possible that the high proportion of variable-rate loans discussed in the 2017 November Financial Stability Report was the result of the PTI regulations, since borrowers could maximise their loan amounts in that way. This corresponds to conclusions in international literature, as modelled by Fuster and Willen (2017) and Campbell and Cocco (2015), as well as to empirical observations, as expressed in the Report „financially stretched households are urged more to choose variable rates" (MNB, 2017).

MNB drove clients towards fixed-rate loans following the introduction of progressive PTI rules by interest periods from o1 October 2018. It, in fact, decided instead of the debtors to opt for more expensive financing to reduce nominal interest rate risk. The picture is even more colourful, as MNB provided the banking sector with long-term interest swaps and bought covered bonds reducing long- 
term interest rates in that way, which also reduced loan interest rates fixed for a longer period (MNB, 2017).

According to MNB statistical data, the difference between variable rates and rates fixed for over 10 years was 160 bps from January 2014 to January 2021, and 156 bps between fixed rates for at least 5 but not more than 10 years pursuant to unconventional monetary measures. As the product range was varied, for instance, several credit institutions had no fixed rates for over 10 years (MNB, 2017), I selected rate fixing for at least 5 but not more than 10 years for reference.

\section{Figure 2}

Average annualised interest rates of HUF loans granted to households and those of HUF deposits placed by them (weighted with contracted amount)

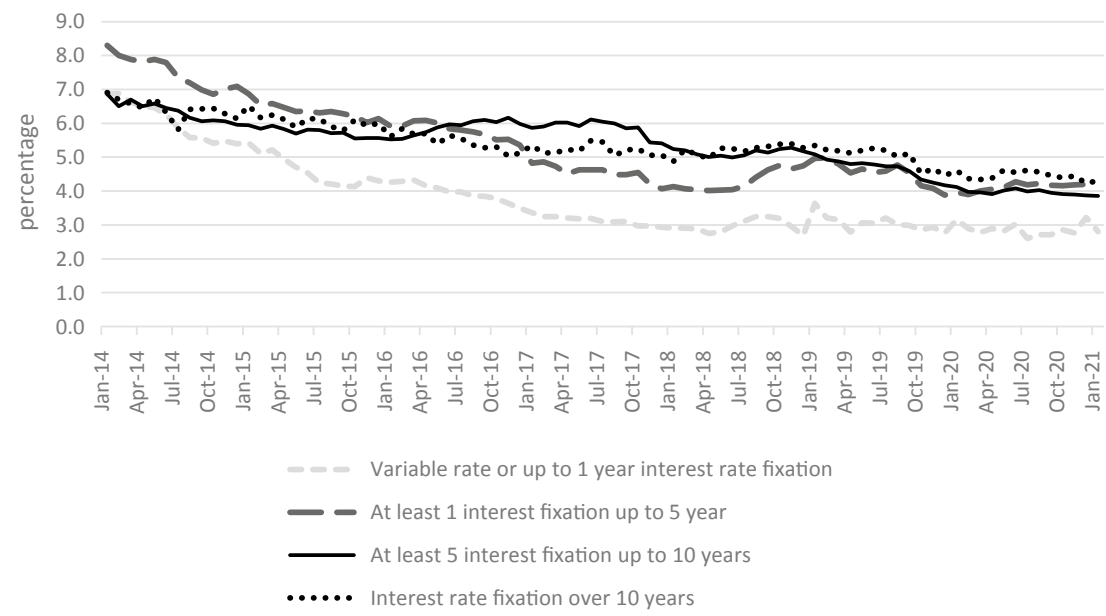

Source: https://www.mnb.hu/letoltes/huogo2-lakossagi-huf.xls

There are no regulatory limitations on maturity, banks can even grant 30-year loans as qualified consumer-friendly loans. The length of maturity, however, has a negative effect on default and proved significant in all econometric models where it was included, partly because many negative events can occur during a longer period, such as divorce, death, or job loss. Further, in terms of annuity loans, interest repayment is higher, and principal is lower at the beginning, so if maturity is long, the outstanding principal will not be reduced materially during the first years. For 30-year loans with 10-year interest periods instalments will be adjusted twice because of changes in reference rates.

An example: the average annualised interest rate of variable-rate housing loans was $3.11 \%$ in July 2017 , while it was $6.05 \%$ of loans with rates fixed for not more 
than 10 years. Provided there are progressive PTI regulations for adjustments, the maturity of a HUF 25-million loan is 14 years and 11 months with HUF 350,000 net income and 50\% PTI. As opposed, the maturity of loans with at least 5 but not more than 10 years of rate fixing will be 21 years and 2 months ceteris paribus. The example shows that a shorter interest period was a good choice not only because of more favourable financing, but rate fixing might have increased contractual maturity significantly because of the PTI regulations.

In terms of annuity loans, prolongation of maturity also means that principal is repaid at a lower rate. For instance, assuming a 25-million 20-year annuity loan at $6.05 \%$ interest, $84.7 \%$ of the principal part of the loan will still be outstanding 5 years later and $64.3 \%$ of it 10 years later. In case of 30 -year maturity, the relevant figures will be $92.9 \% 5$ years later and $83.4 \%$ 10 years later. So, although rate fixing seems to be good hedging strategy against interest rate risk, in the case of a 30year loan with 10 -year rate fixing over $80 \%$ of the loan amount will be exposed to interest rate risk even if repayments are prudent.

In this paper, I do not argue that rate fixing is less favourable than variable rate loans from a financial aspect, but I want to warn readers that it might be accompanied with negative impacts not in focus previously. One of the conclusions is the higher initial instalments and the expected lower net present value (higher loan repayment) by the debtor, which is supported by international research. As far as I know, studies in Hungary have not compared fixed and variable rate loan types from the aspect of financial rate of return. A shift to variable rate loans was possible, in addition to better initial terms, because of adaptation to PTI regulations, i.e., maximising loan amounts, since it was particularly typical of loans with stretched instalments, as seen in the November 2017 Financial Stability Report.

Because of the formula of annuity loans, prolongation of maturity is the next means of adaptation to maximise the loan amount. Fáykiss et al 2018 concluded in 2018 regarding debt cap regulations that prolongation of maturity "is not typical at present" as debt cap regulations were implemented, but statistics by KSH indicate their increasing relevance. 


\section{Figure 3}

Average maturity of housing loans in the average of disbursing institutions

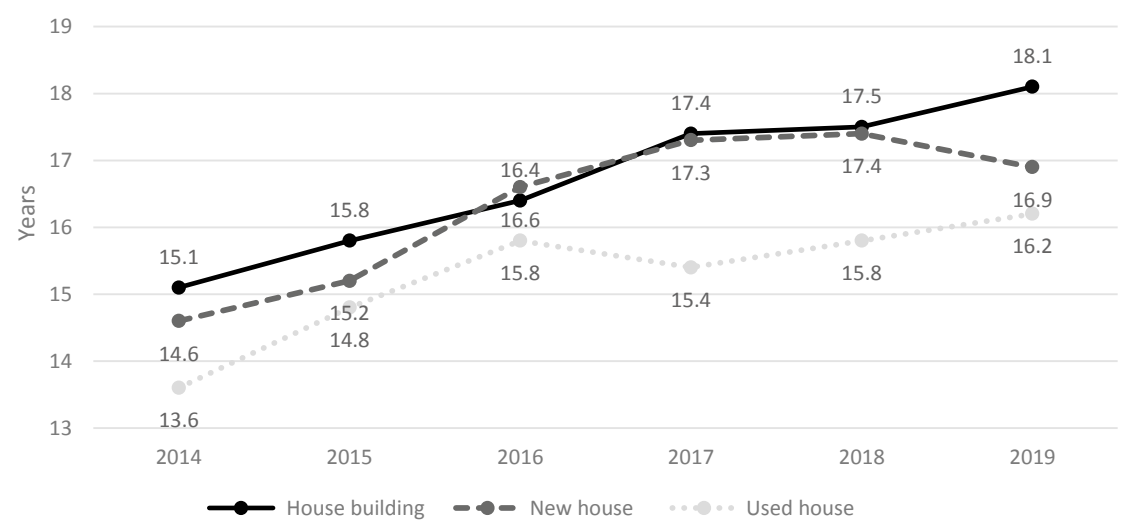

Source: https://www.ksh.hu/docs/hun/xstadat/xstadat_eves/i_zrhoorb.html

The phenomenon was reviewed in the 2020 Macroprudential Report, which found that the effectiveness of PTI limitations was accompanied by the increase of maturity. Average maturity exceeded 17 years by mid-2020. In the Report, maturities with PTI rates of below and above $40 \%$ were separately presented.

\section{Figure 4}

Evolution of average maturities by PTI values for housing loans and home equity loans

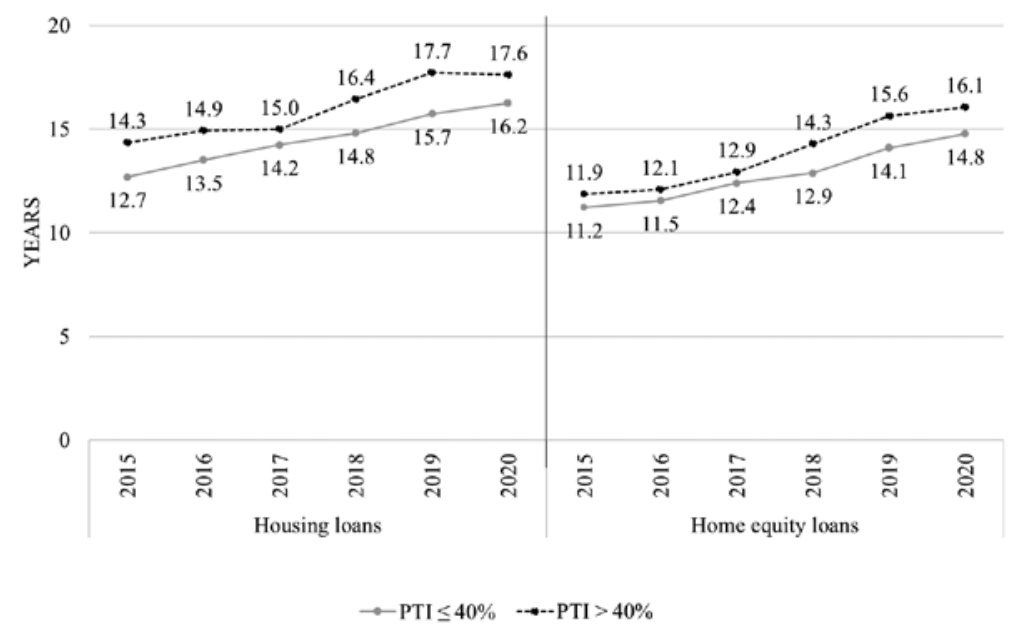

Source: https://www.mnb.hu/letoltes/a-jelentes-abrai-2.xlsx 
The Figure 4 shows a kind of adaptation attitude by debtors; as PTI regulations become effective, debtors respond by prolonging maturity. Although average maturity is still lower than European regulatory limits, 30-year loans have appeared on the market. If PTI regulations prevail, new debt cap regulations can be expected as maturities get longer. According to studies by Linn and Lyons (2020) and Chamboko and Bravo (2020), where PTI at disbursement proved to be significant, maturities positively correlated with default risk. Thus, if the models are accepted to be robust, the increase of maturity caused by PTI regulations may increase default risk.

Another adverse effect is that loan amounts granted are not only subject to income but also to interest level. As one can see in the quantitative example, clients can achieve major excess credit in the event of a small interest adjustment. On the one hand, one can argue that monetary policy and its instruments will be even more effective, as the reduction of interest rates can result in higher-amount loans granted pursuant to the PTI regulations. On the other hand, modelling and considering this additional impact is beyond the framework of standard monetary policy. In the event of undesired effects (such as, over-indebtedness compared to income because of interest rate reduction) the future modification of debt cap regulations can be envisaged, as it did happen in connection with the differentiation by interest periods introduced on o1 October 2018 and the change of income brackets in July 2019.

Considering the above, I propose the introduction of LTI regulations instead of PTI at disbursement. The current PTI rate for loan maturity continues to be a good proxy variable for banks to monitor their clients. However, a LTI limitation would result in loan amounts granted to be independent of the current interest rate level; so, the legal maximum could be calculated and planned in direct proportion to income by potential borrowers. As in the case of LTI the maximum loan amount is given, selecting maturity is up to the individual borrower. They can opt for high instalments for shorter maturity, or they can prefer less stretched instalments for longer maturity. In terms of loan pricing, it is also a question of preference if a borrower opts for more favourable interest rates regarding expected value, or a scheme more protected from interest risk in nominal terms. PTI analysis continues to be a good proxy variable to monitor credit risk, but I believe its value at disbursement is less suitable to assess creditworthiness compared to LTI. 


\section{SUMMARY}

In this paper I reviewed debt cap regulations in Hungary and in Europe as well as in international literature. Reviewing European examples one can state the Hungarian debt cap regulations are among the most complex and most complicated macroprudential intervention measures. Using them the National Bank of Hungary do not only want to regulate the portfolio composition of banks but intend to drive clients towards the schemes deemed desirable, which means HUF loans with long interest periods in the case of housing loans. Although in terms of FX lending both empirical experience and the theory support higher risk, the impact of rate fixing on credit risk is not unambiguous in international literature.

Hungarian LTV regulations correspond to European practice and the approximately $80 \%$ maximum value recommended by models in international literature. Conversely, opinions on PTI regulations differ in international literature. While current PTI seems to be a good indicator to predict default, PTI at disbursement is not significant in certain cases, in addition, it can have undesired incentives. An example for that is the excessive spread of variable rates and preference for longer maturity if clients want to increase their loan amounts. To eliminate that, the National Bank of Hungary allow lower PTI rates subject to interest periods, which means clients can be granted loans at higher initial interest rates. At the same time, the increase of maturity remains an open issue, which can have an adverse effect on default. Because of prolonged maturity, 5 and 10-year fixed-rate loans continue to be exposed to risk resulting from interest rate change even if the risk is lower. In addition, interest rate levels influence maximum loan amounts, so maximum loan amounts granted can change significantly even during a shorter period. As opposed to this, an LTI-based limitation can be calculated easily, so clients can plan loan amounts better, which will not depend on maturity or interest rate level. 


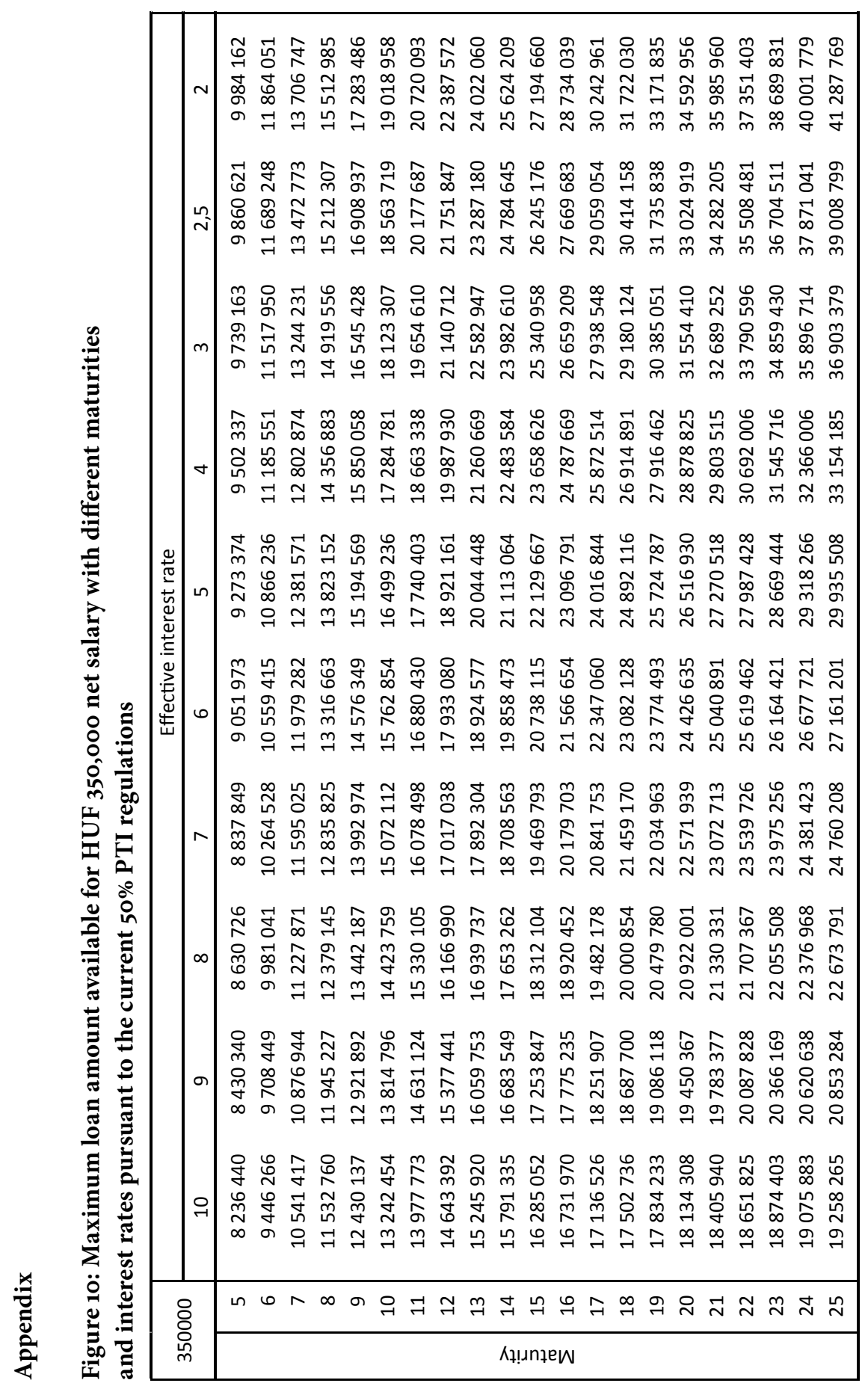




\section{REFERENCES}

Adelino, Manuel - Schoar, Antoinette - Severino, Felipe (2016): Loan Originations and Defaults in the Mortgage Crisis: The Role of the Middle Class. Review of Financial Studies, 29, 1635-1670. https://doi.org/10.1093/rfs/hhw018.

Adelino, Manuel - Schoar, Antoinette - Severino, Felipe (2018): Dynamics of housing debt in the recent boom and great recession, NBER Macroeconomics Annual, University of Chicago Press, 32(1), 265-311. https://doi.org/10.1086/696054.

Agarwal, Sumit - Ambrose, Brent W. - Yao, Vincent W. (2020): Lender steering in residential mortgage markets. Real Estate Economics, 48(2), 446-475. https://doi.org/10.1111/1540-6229.12203.

Al-Bahrani, Abdullah - Su, QIng (2015): Determinants of mortgage pricing: A quantile regression analysis. Journal of Housing Economics, 30, 77-85. https://doi.org/10.1016/j.jhe.2015.10.005.

Allen, Jason - Grieder, Timothy - Peterson, Brian - Roberts, Tom (2020): The impact of macroprudential housing finance tools in Canada. Journal of Financial Intermediation, 42. https://doi.org/10.1016/j.jfi.2017.08.004.

Amromin, Gene - Huang, Jennifer - Sialm, Celmens - Zhong, Edward (2018): Complex mortgages. Review of Finance, 22(6), 1975-2007. https://doi.org/10.1093/rof/rfyo16.

Balás TAmás - Banai ÁdÁm - Hosszú Zsuzsanna (2015): Modelling probability of default and optimal PTI level by using a household survey. Acta Oeconomica, 65(2), 183-209. https://doi. org/10.1556/032.65.2015.2.1.

Berkovec, James A. - Canner, Glenn B. - Hannan, Timothy H. - Gabriel, Suart A. (2018): Mortgage discrimination and FHA loan performance. In GoERING, JOHN - WIENK, Ron (eds.) (1997): Mortgage lending, racial discrimination and federal policy. London: Routledge (1st Ed.), 289-305. https://doi.org/10.4324/9780429448522-7.

Berlinger, Edina (2019): Why APRC is misleading and how it should be reformed. Cogent Economics \& Finance 7(1), 1-18. https://doi.org/10.1080/23322039.2019.1609766.

Bethlendi, ANDRÁs (2015): Bad product development results in systemic market failure - Foreign currency mortgage loans to Hungarian households. Financial and Economic Review, 14(1), 5-30. https://en-hitelintezetiszemle.mnb.hu/letoltes/fer-2015-1-en.pdf

CAmpbell, John Y. - Cocco, JoAo F. (2015): A model of mortgage default. Journal of Finance, 7o(4), 1495-1554. https://doi.org/10.1111/jofi.12252.

Chamboko, Richard - Bravo, Jorge Miguel (2020): A multi-state approach to modelling intermediate events and multiple mortgage loan outcomes. Risks, 8(2), 1-29. https://doi. org/10.3390/risks8020064

Corbae, Dean - Quintin, Erwan (2015): Leverage and the foreclosure crisis. Journal of Political Economy, 123(1), 1-65. https://doi.org/10.1086/677349

Demyany K, Yuliya - Loutskina, Elena (2016): Mortgage companies and regulatory arbitrage. Journal of Financial Economics, 122(2), 328-351. https://doi.org/10.1016/j.jfineco.2016.07.003.

Deng, Carlos - Quigley, John M. - Order Van, Robert (200o): Mortgage terminations, heterogeneity and the exercise of mortgage options. Econometrica, 68(2), 275-307. https://doi. org/10.1111/1468-0262.00110.

Enoch, Charles - Everaert, Luc - Tressel, Thierry - Zhou, Jianping (2013): Mortgage Markets and Foreclosure Processes in Europe and the United States (Chapter 22). In From Fragmentation to Financial Integration in Europe. USA: International Monetary Fund. https:// doi.org/10.5089/9781484387665.071.

FÁykiss Péter - Palicz Alexandr - Szakács János - Zsigó Marcell (2018): Experiences of Debt Cap Regulations in Hungarian Retail Lending. Financial and Economic Review, 17(1), 3461. https://en-hitelintezetiszemle.mnb.hu/letoltes/fer-17-1.pdf. 
Fuster, Andreas - Willen, Paul S. (2017): Payment size, negative equity, and mortgage default. American Economic Journal: Economic Policy, 9(4), 167-191. https://doi.org/10.1257/ pol.20150007

Ganong, Peter - Noel, Pascal (2020): Liquidity versus wealth in household debt obligations: Evidence from housing policy in the great recession. American Economic Review, 110(10), 31003138. https://doi.org/10.1257/aer.20181243.

Gerardi, Kristopher - Herkenhoff, Kyle F. - Ohanian, Lee E. - Willen, Paul S. (2018): Can't Pay or Won't Pay? Unemployment, Negative Equity, and Strategic Default. The Review of Financial Studies, 31(3), March, 1098-1131. https://doi.org/10.1093/rfs/hhx115.

Gete, Pedro - Reher, Michael (2016): Two extensive margins of credit and loan-to-value policies. Journal of Money, Credit and Banking, 48(7), 1397-1438. https://doi.org/10.1111/jmcb.12337.

Greenwald, Daniel L. (2016): The Mortgage Credit Channel of Macroeconomic Transmission. MIT Sloan Research Paper, No. 5184-16. https://doi.org/10.2139/ssrn.2735491.

Guiso, Luigi - SAPienza, PAOlo - Zingales, Luigi (2013): The determinants of attitudes toward strategic default on mortgages. Journal of Finance, 68(4), 1473-1515. https://doi.org/10.1111/ jofi.12044.

Harrison, David M. - Noordewier, Thomas G. - Yavas, Abdullah (2004): Do riskier borrowers borrow more? Real Estate Economics, 32(3), 385-411. https://doi.org/10.1111/j.108o8620.2004.00096.x.

Hatchondo, Juan Carlos - Martinez, Leonardo - Sánchez, Juan M. (2015): Mortgage defaults.JournalofMonetaryEconomics, 76,173-190.https://doi.org/10.1016/j.jmonec0.2015.09.011.

Kelly, Robert - O’Toole, Conor (2018): Mortgage default, lending conditions and macroprudential policy: Loan-level evidence from UK buy-to-lets. Journal of Financial Stabilit,y 36, 322-335. https://doi.org/10.1016/j.jfs.2018.03.008.

Kim, Hyeongjun - Cho, Hoon - Ryu, Doojin (2018): Characteristics of mortgage terminations: An analysis of a loan-level dataset. Journal of Real Estate Finance and Economics, 57(4), 647-676. https://doi.org/10.1007/s11146-017-9620-5

Lin, Tyrone T. - Lee, Chia-Chi - Chen, Chun-Hung (2011): Impacts of the borrower's attributes, loan contract contents, and collateral characteristics on mortgage loan default. Service Industries Journal, 31(9), 1385-1404. https://doi.org/10.1080/02642060903437535.

Linn, Andrew- Lyons, Ronan C. (2020): Three triggers? Negative equity, income shocks and institutions as determinants of mortgage default. Journal of Real Estate Finance and Economics, 61(4), 549-575. https://doi.org/10.1007/s11146-019-09711-1.

MNB (2016): Makroprudenciális jelentés [Macroprudential Report]. https:/www.mnb.hu/letoltes/ makroprudencialis-jelentes-hu.pdf.

MNB (2017): Pénzügyi stabilitási jelentés. 2017. november [Financial Stability Report. November 2017]. https://www.mnb.hu/letoltes/stabilitasi-jelentes-2017-november-hun.PDF.

MNB (2020): Makroprudenciális jelentés [Macroprudential Report] https:/www.mnb.hu/letoltes/ makroprudencia-lis-jelente-s-2020.pdf.

Mamonov, Stanislav - Benbunan-Fich, Raquel (2016): Predicting mortgage default: Lessons from data mining fannie mae mortgage portfolio. Paper presented at the Proceedings of the International Conferences on ICT, Society, and Human Beings 2016, Web Based Communities and Social Media 2016, Big Data Analytics, Data Mining and Computational Intelligence 2016 and Theory and Practice in Modern Computing 2016 - Part of the Multi Conference on Computer Science and Information Systems 2016, 187-194.

Oyedokun, Tunbosun Biodun - Adewusi, Amos Olaolu - Bello, Oyewole Mustapha (2015): Impact of borrower's attributes on mortgage default: Evidence from nigerian lending mar- 
ket. Pacific Rim Property Research Journal, 21(3), 259-274. https://doi.org/10.1080/14445921.201 6.1140713 .

Tam, Mercury Wai-Yin - Hui, Eddie - Zheng, Xian (2010): Residential mortgage default behaviour in hong kong. Housing Studies, 25(5), 647-669. https://doi.org/10.1080/02673037.201 0.483584 .

Yilmazer, Tansel - Babiarz, Patryk - Kiss, D. E. (2012): The role of lending practices on the foreclosure crisis: Evidence from Indiana and Ohio. Family and Consumer Sciences Research Journal, 40(4), 398-416. https://doi.org/10.1111/j.1552-3934.2012.02119.x.

\section{Legislative reference}

32/2014. (IX. 10.) MNB rendelet a jövedelemarányos törlesztőrészlet és a hitelfedezeti arányok szabályozásáról [32/2014. (IX. 10.) MNB Decree on the regulation of income-related instalments and loan-to-value ratios] 